\title{
Impact of Vision 20:2020 Policy in Nigeria: A Study of Selected Local Government Areas in Ebonyi State
}

\author{
Nwori Benjamin Chukwuma ${ }^{1, *}$, Ukwa Christopher Nwambam² \\ ${ }^{1}$ Department of Political Science, EBCOEI, Ebonyi, Nigeria \\ ${ }^{2}$ Department of Computer Science, EBCOEI, Ebonyi, Nigeria \\ *Corresponding author: nworibenjamin@gmail.com
}

Received November 24, 2018; Revised December 27, 2018; Accepted February 12, 2019

\begin{abstract}
Nations all over the universe usually adopt agenda to address their peculiar problems. Nigeria as a nation has had series of reforms to restructure the state so as to bring about desired changes in all spheres of the state economy. Nigeria being the christened "giant of Africa continent" with commanding population and buoyant economy has played prominent roles in African and international affairs in terms of trade agreement, technical assistance, manpower training, peace process and conflict resolution. After independence, successive administration in Nigeria had initiated one programme or the other to put Nigeria socio-political and economic base on a sound footing. Vision 20:2020 policy is one of such national plans aimed at launching Nigeria into one of the leading economies among comity of nations by the year 2020 and to raise the declining status of the country and restore her pride of place in Africa and the global community.
\end{abstract}

Keywords: impact, vision, 20:2020, policy, local government

Cite This Article: Nwori Benjamin Chukwuma, and Ukwa Christopher Nwambam, "Impact of Vision 20:2020 Policy in Nigeria: A Study of Selected Local Government Areas in Ebonyi State." American Journal of Educational Research, vol. 7, no. 2 (2019): 145-152. doi: 10.12691/education-7-2-5.

\section{Introduction}

Every country including Nigeria has agenda with which the intention of the society can be achieved. Nigeria as a nation has existed for over forty years, but had undergone series of reforms aimed at bringing changes within the social structures and the entire economy of the state. Nigeria is regarded as the giant of Africa in terms of population and buoyant economy in sub-Saharan Africa. Nigeria as a colonial creation is mostly endowed with huge deposits of both human and material resources. Nigeria has also played significant roles in trade agreement among African Union (AU) and in Economic Community of West African States (ECOWAS) as well as in peace processes and conflict resolutions in war torn countries like Liberia, Sudan, Congo, Somalia etc.

After Nigeria Independence in 1960, successive regimes in the country have in one way or the other, initiated plans on how to manage the huge endowment and the large investments made between that time and 1990's and how to maintain the deteriorating infrastructure and services, coupled with low quality and standard of education in the country. In the past, Nigeria had several national plans stretching over specified duration with the vision to achieve certain purpose in the overall sectors of the economy. Such laudable plans include: War Against Indiscipline (WAI), Health for all by the year 2000, Operation Feed the Nation (OFN), Green Revolution, vision 2010, Roll back Malaria, Re-branding Campaign, Economic and Finance Crime Commission (EFCC). Independent Corrupt Practices Commission, (ICPC), Vision 2020, Seven Point Agenda. All these structures and plans were put in place to raise the declining status of Nigeria as a nation and to take our pride of place in Africa and the world at large.

\subsection{Statement of the Problem}

Nigeria in the continental ranking is regarded as the mouth piece of Africa and a leading economy because of the rich endowment with gas and oil which place her as the sixth largest oil exporter. As the giant of Africa, Nigeria has played prominent roles in all matters affecting the continent in most international discourse concerning Africa. It is also evidently clear that Nigeria has strong potentials for growth with the considered resource base of human and material endowment. Unfortunately, Nigeria development history showed that there is abysmal decline in the welfare of the citizens, increased social instability and shattered economy which have in one way or the other undermined the development of this country for more than forty years.

It is also disheartening that despite the huge amount of money accruing from oil sales, Nigeria is still very backward in terms of development. Infrastructures are not maintained, corruption is very high, quality and standard of education have fallen, insecurity is growing at alarming rate, health system is deteriorating, crime wave is on the 
high side, the economy is very unstable and unpredictable and a lot more. It is against this back drop that the federal government of Nigeria under President Umaru Musa Yar'adua came up with the idea of vision 2020 with the objective of placing Nigeria among the top twenty economies of the world by the year 2020 .

\subsection{Purpose of the Study}

The purpose of this study includes:

1. To investigate why Nigeria economy has continued to dwindle despite the huge resource endowment in the country.

2. To know who are responsible for the social and economic failures of the country.

3. To establish the objectives of vision 2020

4. To investigate why other development plans have failed

5. To make recommendations on how to achieve the core objectives of vision 2020.

\subsection{Significance of the Study}

This study will be of special benefits to categories of people and institutions. First, it will be beneficial to policy makers, especially those charged with the planning and execution of the philosophy of vision 2020. Again, Nigeria citizens stand to gain from this study, because it will keep them abreast of what vision 2020 is all about.

More so, the study will be of great importance to student and researchers on public and national issues.

Finally, government and non-government bodies will also benefit from the study.

\subsection{Scope of the Study}

This study will focus only on vision 2020 as policy initiative of President Yar'adua administration. This is because the study cannot afford to take holistic view of all the reforms embarked upon by successive administration in Nigeria.

\subsection{Research Questions}

This research on the vision 20:20:20 policy in Nigeria with focus on achievements, challenges and way forward will be guided by the following research questions.

1. Why has Nigeria economy continued to dwindle despite the huge natural resource endowment in the country?

2. Who are responsible for the social and economic failures in the country?

3. What are the objectives of vision $20: 20: 20$ policy in Nigeria?

4. What factors contributed to the failures of previous developmental plans in Nigeria what measures should be adopted to achieve the core objectives of vision 20;20; 20 policy in Nigeria.

\section{Review of Related Literature}

Vision 2020 is a federal government initiative aimed at achieving certain objectives for overall national development and growth. The committee on vision 2020 was set up in 2007 by the democratic administration of President Musa Yar; adua with the objectives of introducing policies that could change the livelihood of every Nigerian from 2020. Triumph newspaper of Sunday (2009) asserted that the previous administrations had at various times declared intention to pursue a vision that places Nigeria as a leading economy, but the administration of President Yar'adua was committed to placing Nigeria among twenty economies of the world by the year 2020. Meanwhile, Pearson [1] defined vision as the knowledge and imagination that are needed in planning for the future with a clear purpose.

However, the comprehensive framework of vision 2020 project focuses on stimulating economic growth and sustainable development which will place Nigeria among the leading economies like United States of America, Japan and Germany. It also implies that certain economic indices such as Gross Domestics Products (GDP), Gross National Product (GNP), and personal income have to match with those of the developed countries of the world. In other words, the indices must be in conformity with the stipulated principles of International Monetary Fund (IMF). In the words of Ibrahim [2], vision 20:2020 aims at raising Nigerian economy to an industrialized one and to be technologically advanced with a vibrant educational system that meet with the expectations and growth challenges of the modern time.

Vision 20:2020 also hinges on provision of adequate infrastructure and social services to support economic growth such as power generation, distribution and supply, transportation, workable communication system that support the demands of the modern information communication technology(ICT). The objectives of vision 20:2020 project are aimed at raising the technological driven agricultural and enhanced food security to attract foreign exchange. It encourages a blossom manufacturing sector, efficient and self-sufficient health services, good governance, corrupt free society, effective financial regulation, transparency, accountability in public matters. According to Todaro and Smith [3], by 2007|8 UNDP Human Development Rating (HDR), Nigeria was the $158^{\text {th }}$ out of 175 United Nations Member Countries.

Summarily, Vision 2020 is in tune with the seven point agenda of the Yar'adua's administration as state below: power and energy, food security and agriculture, wealth creation, mass transportation, land reform, security and qualitative and functional education.

\subsection{Implementation Structure of Vision 20:20:20 Policy}

According to Onyenekenwa ([4]:2), Vision 20:20:20 policy is structured to operate on institutional platform for implementation of the policy goals. Such institutional arrangements include:

(1) Office of Chairman: The Vision is headed by the President and Commander-in-chief of the federal Republic of Nigeria. The chairman is to provide the needed leadership and direction to galvanize developmental strides in the nation.

(2) National Steering Committee: National Steering Committee is headed by the Honorable Minister or 
Deputy Chairman of National Planning Commission. The sole concern of the committee is to develop methodology and guidelines for all ministries, departments and agencies.

(3) State Stakeholders Committee: At this level, the committee usually comprise of 20-25 eminent members of the state with interest and knowledge on the vision and mission of the policy.

(4) National Technical Working Groups: This body comprises 25 experts drawn from public and private sectors. It provides technical support to National and Steering Committee such as articulating key economic issues and defining proposed policy targets.

(5) National Planning Commission: National Planning Commission is another institution for implementation of numerous goals of Vision 20:2020 in Nigeria.

\subsection{Problems of Vision 2020}

The 2020 vision is a laudable policy which if adequately followed will enhance economic development in line with Millennium Development Goals (MDG). But like any other programme, the policy is faced with a lot of challenges. These problems include:

The instability of the Economy: Various factors such as bad governance, embezzlement, poor purchasing power decaying economic institutions etc have resulted to unstable economy of the country.

- Failed Educational System: Education is the fulcrum of every developmental stride. In Nigeria, the deplorable state of the education sector has serious negative implications on the set goals of vision 20:2020. According to Jhingan [5], qualitatively, the type of education being imparted on the majority of the school children is ill-suited to the development needs of Nigeria where appropriate education approach is yet to be given attention.

- Lack of Efficient Social Amenities: In Nigeria, provision of social amenities is inadequate and the existing ones are in efficient.

- Lack of Skilled Manpower: Nigeria has low quality skilled manpower in relation to science and technology education and the ability to harness the endowed natural resources. Nigeria has surplus labour force, but lacks human capital- the number of people with the requisite skills, education and experience needed for economic and political development.

- Poor Investment: Investment propensity in Nigeria is very low.

- Poverty: Poverty and inequality in the country is very high which manifest in low school enrollment, poor health services, and poor food security.

\subsection{Historical Antecedent of Policy Summersaults/Failures}

Nigeria has in the past paraded laudable policies and reforms; But in the view of Ebigbo [6], Nigeria policies vision and agenda often end up as paper works rubbished by insincere implementation efforts and corruption. He cited an example of National Economic Empowerment and Development (NEEDS) which has not sorted Nigeria needs. Onah [7] pointed out that for decades after the national development planning in Nigeria; empirical indices such as widespread poverty, large scale unemployment, low capacity utilization, illiteracy, urban congestion, huge debt burden, inadequate and decayed social and physical infrastructure have not been eradicated or meaningfully mitigated.

\subsection{Discontinuity of Policies}

Okoigbo [8] succinctly observed that a typical Nigerian government is played with institutional and structural inconsistencies and discontinuity. Hence, government officials are no always at home or committed to the developmental policies of their predecessors and that is why the national landscape is littered with uncompleted and abandoned projects. As noted by Eneh [9], Nigeria's under-development vision and programme. Policy and programme reversal and failures are common in Nigeria.

\subsection{Theoretical Framework}

Theories are reasoned supposition put forward to explain facts or events. Nwori [10] defined theory as cognitive map which help to organize reality and to make some sense to several number of events taking place all over the world. However, theories are usually subjected to rigorous process to prove facts or phenomena. In this study, classical and Neo-classical Theory will apply. This theory postulates that the growth of any economy is often determined by the volume of capital investment and labour. The import of this theory is that development tends to thrive better where capital flow more into areas that guarantee high rate of returns, while labour tend to migrate into areas that are characterized by high wage rate. The implication of this theory on the subject matter is that for development of any sort to occur in a rural dominated society like Nigeria, certain measures have to be adopted to raise the rate of return on capital investment and wages to labour which reflects on vision 20:20:20 objectives.

\subsection{Empirical Review}

Onyenekenwa Cyprian Eneh wrote on the Topic: Nigeria's Vision 20:20:20 Issues, Challenges and Implementations for Development Management. The article is published in the Asian Journal of Rural Development. Vol. 1 (1) in 2011.

Onyenekenwa in his introductory page defined vision 20:20:20 as a dream statement that Nigeria will become one of the first 20 economics in the world by the year 20:20. Citing Abdulhamid [11], he traced the history of the dream to a research conducted by economists at an American Investment Bank, a fall out of which was a prediction that Nigeria would be in the league of 20 top economics by the year 2025. This prediction was anchored on the premise that Nigeria's abundant human and material resources would be properly managed and channeled to achieve the set economic goal.

He articulated operational the operational and institutional structure for realization of vision 20:2020 objectives. Such institution organs include;

National Counsel on Vision 20:2020 usually headed by the president and commander-in-chief of the armed forces.

National steering Committee on Vision 20:2020 headed by the Hon. Minister or Chairman National Planning Commission. 


\subsection{State 20:2020 Stake Holders Committee}

National technical Working Groups which comprised of maximum of 25 groups of experts with the mandate to provide technical support to National Steering Committee.

National Planning Commission which provide the needed planning strategies for the overall realization of the vision's objectives. Relevant literature to the subject matter was reviewed by the author. He noted that Nigeria was the $158^{\text {th }}$ out of 175 United Nations member countries. He emphasized that developing world is made up of sub - Saharan Africa, North Africa, Middle East, Latin America and the Caribbean while the developed nations were identified as North America, Japan, Australia and Newzealand.

\section{Methodology}

Onyenekenwa [2] applied a Critical Research Method in analyzing available secondary information and data. It compared recent development indication for Nigeria with those of the advanced countries of the first 20 which Nigeria is aspiring for by the year 20:2020. The research analysis drew a comparisons in some cases between the developmental statistics for different periods on how slowly Nigeria's development grows to aspire to become one of the first 20 economics by 20:2020.

The paper had conceptual and theoretical framework with proper conclusion and references.

\subsection{Gap in Knowledge}

The following areas were identified as gap in knowledge:

The research was conducted in 2011 and had not accommodated recent issues on vision 20:2020 initiative.

The research was not centered in Ebonyi State where the current research has selected a study area.

Scope, titles were not tailored the same way.

\subsection{Research Methodology}

This section will be discussed under the following sub-headings: - Design of the Study, Area of the Study, Population, Sample and Sampling technique, Instrument for data Collection, Validation of instrument, Reliability of the instrument, procedure for data collection and Method of data Analysis.

\subsection{Design of the Study}

This study is essentially a survey research and depends solely on primary and secondary data for examination of the Impact of Vision 20:2020 in Nigeria. A study of selected local government from three zones of Ebonyi State viz: Ebonyi, Ohaukwu, Ezza South, Ikwo, Afikpo North and Ohaozara local government areas.

\subsection{Area of Study}

The research covered Six local government areas spread across the geographical zones of Ebonyi State. Ebonyi North Zone: Ebonyi and Ohaukwu LGA. Ebonyi
Central Zone: Ezza South and Ikwo LGA. Ebonyi South Zone: Afikpo North and Ohaozara LGA.

\subsection{Population of the Study}

The population of this study stood at 6,000 people drawn from six selected local government areas under study.

\subsection{Sample and Sampling Technique}

A Sample of 600 respondents will be used in collection of data in relation to impact of Vision 20:2020 Policy in Ebonyi State. While random sampling technique will apply during collection of data from the sampled respondents. This is necessitated by the fact every member of the population has equal chance of being selected. It is not possible to get the opinions or perceptions of all the members of the population. Yoyo Yamani formula will be adopted in determining the sample size.

$$
n=\frac{N}{I+N(e)^{2}}
$$

Where $\mathrm{n}=$ Sample size

$\mathrm{N}=$ population size

$\mathrm{e}=$ Level of Significance $=5 \%=0.05$

$\mathrm{I}=$ Constant.

\subsection{Instrument for Data Collection}

The instruments used in the study for data collection were observations, questionnaire and interview. The researcher visited the local government areas concerned to ascertain the level of impact of the vision policy via the use of interview of the illiterate respondents and questionnaires to the literate respondents.

\subsection{Validation of Instrument}

Prior to the administration of the instrument, draft copy of the questionnaire passed through supervision of experts in research and measurement and evaluation.

\subsection{Reliability of Instrument}

The reliability of the measuring instrument was determined by administering a pre-test questionnaire randomly to selected respondents within the local areas constituting the radius of the study area.

\subsection{Procedure for Data Collection}

The data for this study was collected by the researcher with the aid of research assistants administered the questionnaire and conducted the interview with illiterate respondents. The interview recorded and the filled questionnaires were retrieved for analysis.

\subsection{Method of Data Analysis}

All data collected were assembled in tabula form using simple frequency and percentage analysis. 


\section{Presentation of Table and Table Analyses}

Table 1: Distribution Table: A Table Showing the Questionnaire Items Distributed to the Respondents.

\section{Analysis:}

The following are the records in the below Table 1:

In Ebonyi North Senatorial Zone, Ebonyi LGA recorded the total of $96(16 \%)$ with $88(16.3 \%)$ returned responses, and $8(13.3 \%)$ unreturned responses. and Ohaukwu LGA has the total of $104(17.3 \%)$, with $82(15.2 \%)$ and $22(37 \%)$. In Ebonyi Central Senatorial Zone, Ezza South LGA recorded the total of $116(19.3 \%)$ with $105(19.4 \%)$ returned responses, and 11(18.3\%) unreturned responses. and Ikwo LGA has the total of 84(14\%), with 79(14.6\%) and 5(8.3\%). In Ebonyi South Senatorial Zone, Afikpo North LGA recorded the total of $107(18 \%)$ with $98(18.1 \%)$ returned responses, and 9(15\%) unreturned responses. and Ohaozara LGA has the total of 93(16\%), with 88(16.3\%) and 5(8.3\%).

The total questionnaire items given to the respondents in the three senatorial zones and the six Local Government Areas, comprising: Ebonyi North, Ebonyi Central and Ebonyi South is 600. The respondents that returned their responses are 540(90\%) and those who did not return any responses are $60(10 \%)$.

Table 2: A Table showing the Extent Nigeria Economy had continued to dwindle despite the huge natural resource endowment in the country.

\section{Analysis:}

In Table 2 below, the respondents who strongly agreed that instability of the economy of Nigeria leads to economic dwelling of the country are 330 (61.1\%), while 102 (18.8\%) agreed, 91 (17\%) strongly disagreed and 17 (3.1\%) disagreed with the assertion.

410 (76\%) respondents strongly agreed that ignorance/greed and miss-appoint lead to the economic dwelling of the country while $56(10.4 \%)$ agreed with the assertion. 51(9.4\%) strongly disagreed and 23 (4.2\%) disagreed.
504 (93.3\%) respondents strongly agreed that failed economic and education systems lead to the economic dwelling of the country while 28 (5.1\%) agreed with the assertion. 5(0.9\%) strongly disagreed and 3(0.5\%) disagreed. 225 (42\%) respondents strongly agreed that inadequate of the necessary technical know-how lead to the economic dwelling of the country while 159(29.2\%) agreed with the assertion. 109(20.2\%) strongly disagreed and 48(9\%) disagreed.

Table 3: A Table Showing the People who are Responsible for the Social and Economic Failures of the Vision 2020 in Nigeria.

\section{Analysis:}

Referencing Table 3 below, the respondents who strongly agreed that policy makers who are responsible for the initiation of the Vision 2020 Principles are responsible for the social and economic failure of the vision 2020 in Nigeria are 239 (44.3\%), while 128 (23.7\%) agreed, $121(22.4 \%)$ strongly disagreed and 52(9.6\%) disagreed with the assertion.

The respondents who strongly agreed that the politicians who manipulate the implementation of the vision 2020 are responsible for the social and economic failure of the vision 2020 in Nigeria are 343(63.5\%), while 112 (20.7\%) agreed, 52(9.6\%) strongly disagreed and 33(6.1\%) disagreed with the assertion.

The respondents who strongly agreed that the Administrators who translate the policy in real terms are responsible for the social and economic failure of the vision 2020 in Nigeria are 251(46.5\%), while 182 (33.7\%) agreed 93(17.2\%) strongly disagreed and 14(2.6\%) disagreed with the assertion.

The respondents who strongly agreed that National Technical Working Groups who are unable to provide the technical Support to National Steering Committee are responsible for the social and economic failure of the vision 2020 in Nigeria are 374(69.3\%), while 155(28.7\%) agreed $7(1.3 \%)$ strongly disagreed and $4(0.7 \%)$ disagreed with the assertion.

Table 1. Distribution Table: A Table Showing the Questionnaire Items Distributed to the Respondents

\begin{tabular}{|c|c|c|c|c|c|}
\hline $\mathbf{S} / \mathbf{N}$ & Senatorial Zones & LGA & No of Questionnaire Items & No Filled and Returned & No unfilled/ unreturned \\
\hline \multirow{2}{*}{1} & \multirow{2}{*}{ Ebonyi North } & Ebonyi & $96(16 \%)$ & $88(16.3 \%)$ & $8(13.3 \%)$ \\
\hline & & Ohaukwu & 104(17.3\%) & $82(15.2 \%)$ & $22(37 \%)$ \\
\hline \multirow{2}{*}{2} & \multirow{2}{*}{ Ebonyi Central } & Ezza South & $116(19.3 \%)$ & $105(19.4 \%)$ & $11(18.3 \%)$ \\
\hline & & IKWO & $84(14 \%)$ & $79(14.6 \%)$ & $5(8.3 \%)$ \\
\hline \multirow{2}{*}{3} & \multirow{2}{*}{ Ebonyi South } & Afikpo North & $107(18 \%)$ & $98(18.1 \%)$ & $9(15 \%)$ \\
\hline & & Ohaozara & $93(16 \%)$ & $88(16.3 \%)$ & $5(8.3 \%)$ \\
\hline 4 & Total & 6 & $600(100 \%)$ & $540(90 \%)$ & $60(10 \%)$ \\
\hline
\end{tabular}

Source: Authors’ Survey, 2018.

Table 2. A Table showing the Extent Nigeria Economy had continued to dwindle despite the huge natural resource endowment in the country

\begin{tabular}{|c|c|c|c|c|c|c|}
\hline $\mathbf{S} / \mathbf{N}$ & Item & SA & A & SD & D & Total \\
\hline 1 & $\begin{array}{l}\text { Instability of the economy of Nigeria leads to economic } \\
\text { dwelling of the country }\end{array}$ & 330 (61.1\%) & 102 (18.8\%) & 91 (17\%) & 17 (3.1\%) & $540(100 \%)$ \\
\hline 2 & $\begin{array}{l}\text { Ignorance/greed and miss-appoint lead to the economic } \\
\text { dwelling of the country }\end{array}$ & 410 (76\%) & 56 (10.4\%) & $51(9.4 \%)$ & $23(4.2 \%)$ & $540(100 \%)$ \\
\hline 3 & $\begin{array}{l}\text { Failed economic and education systems lead to the } \\
\text { economic dwelling of the country }\end{array}$ & 504 (93.3\%) & 28 (5.1\%) & $5(0.9 \%)$ & $3(0.5 \%)$ & $540(100 \%)$ \\
\hline 4 & $\begin{array}{l}\text { Inadequate of the necessary technical know-how lead to } \\
\text { the economic dwelling of the country }\end{array}$ & 225 (42\%) & 159 (29.2\%) & 109 (20.2\%) & 48 (9\%) & $540(100 \%)$ \\
\hline
\end{tabular}

Source: Authors’ Survey, 2018. 
Table 3. A Table Showing the People who are Responsible for the Social and Economic Failures of the Vision 2020 in Nigeria

\begin{tabular}{|c|c|c|c|c|c|c|}
\hline $\mathrm{S} / \mathbf{N}$ & Item & SA & A & SD & D & Total \\
\hline 1 & $\begin{array}{l}\text { Policy makers who are responsible for the initiation of the Vision } \\
2020 \text { Principles are responsible for the social and economic failure of } \\
\text { the vision } 2020 \text { in Nigeria }\end{array}$ & 239 (44.3\%) & 128 (23.7\%) & $121(22.4 \%)$ & $52(9.6 \%)$ & $540(100 \%)$ \\
\hline 2 & $\begin{array}{l}\text { The politicians who manipulate the implementation of the vision } \\
2020 \text { are responsible for the social and economic failure of the vision } \\
2020 \text { in Nigeria }\end{array}$ & 343(63.5\%) & 112 (20.7\%) & $52(9.6 \%)$ & $33(6.1 \%)$ & $540(100 \%$ \\
\hline 3 & $\begin{array}{l}\text { The Administrators who translate the policy in real terms are } \\
\text { responsible for the social and economic failure of the vision } 2020 \text { in } \\
\text { Nigeria }\end{array}$ & 251(46.5\%) & 182 (33.7\%) & $93(17.2 \%)$ & $14(2.6 \%)$ & $540(100 \%)$ \\
\hline 4 & $\begin{array}{l}\text { National Technical Working Groups who are unable to provide the } \\
\text { technical Support to National Steering Committee are responsible for } \\
\text { the social and economic failure of the vision } 2020 \text { in Nigeria }\end{array}$ & 374(69.3\%) & $155(28.7 \%)$ & 7(1.3\%) & $4(0.7 \%)$ & $540(100 \%)$ \\
\hline
\end{tabular}

Source: Authors’ Survey, 2018.

Table 4: A Table Showing the Objectives of the Vision 2020 in Nigeria.

\section{Analysis:}

In Table 4, the respondents who strongly agreed that one of the objectives of the Vision 2020 Policy in Nigeria is introducing policies to bring about quality changes in the livelihood of every Nigerian by the year 2020 are 342 (63.3\%), while $178(32.9 \%)$ agreed, $13(2.4 \%)$ strongly disagreed and 7(1.3\%) disagreed with the assertion.

The respondents who strongly agreed that one of the objectives of the Vision 2020 Policy in Nigeria is stimulating sustainable economy to launch the nation among the twenty leading economies by 2020 are 499 (92.4\%), while 34(6.3\%) agreed, 5(0.9\%) strongly disagreed and $2(0.4 \%)$ disagreed with the assertion.

The respondents who strongly agreed that one of the objectives of the Vision 2020 Policy in Nigeria is raising Nigerian's industrialized and technological sectors to advanced height by 2020 are 501(92.8\%), while 29(5.4\%) agreed, $7(1.3 \%)$ strongly disagreed and 3(0.5\%) disagreed with the assertion.

The respondents who strongly agreed that one of the objectives of the Vision 2020 Policy in Nigeria is the provision of adequate infrastructure, health services, quality education and food security are 516(95.6\%), while 19(3.5\%) agreed, 5(0.9\%) strongly disagreed and 0(0\%) disagreed with the assertion.

Table 5: A Table showing the Factors Contributing to the Failure of the Previous Developmental Plans in Nigeria.

\section{Analysis:}

In Table 5 below, the respondents who strongly agreed that some of the factors contributing to the failure of the previous developmental plans in Nigeria are the instability of the economy associated with bad governance, embezzlement and low purchasing power etc are 478 (89\%), while 26(4.8\%) agreed, 29(5.4\%) strongly disagreed and $7(1.3 \%)$ disagreed with the assertion.

The respondents who strongly agreed that one of the factors contributing to the failure of the previous developmental plans in Nigeria is the failure/deplorable disposition of the educational system in Nigeria are 349 (65\%), while 102(19\%) agreed, 53(10\%) strongly disagreed and 36(7\%) disagreed with the assertion.

The respondents who strongly agreed that one of the factors contributing to the failure of the previous developmental plans in Nigeria is the inadequate skilled manpower with requisite training and experience for economic development are 472(87.4\%), while 36(7\%) agreed, 233(4.2\%) strongly disagreed and 9(1.7\%) disagreed with the assertion.

The respondents who strongly agreed that one of the factors contributing to the failure of the previous developmental plans in Nigeria is high level of poverty contributing to illiteracy, poor health services, low investments prosperity and inadequate food security are 520(96.3.4\%), while 18(3.3\%) agreed, $2(0.4 \%)$ strongly disagreed and $0(0 \%)$ disagreed with the assertion.

Table 4. A Table Showing the Objectives of the Vision 2020 in Nigeria

\begin{tabular}{|c|c|c|c|c|c|c|}
\hline $\mathbf{S} / \mathbf{N}$ & Item & SA & A & SD & D & Total \\
\hline 1 & $\begin{array}{l}\text { One of the objectives of the Vision } 2020 \text { Policy in Nigeria is introducing } \\
\text { policies to bring about quality changes in the livelihood of every Nigerian by } \\
\text { the year } 2020\end{array}$ & 342 (63.3\%) & 178(32.9\%) & $13(2.4 \%)$ & $7(1.3 \%)$ & $540(100 \%)$ \\
\hline 2 & $\begin{array}{l}\text { One of the objectives of the Vision } 2020 \text { Policy in Nigeria is stimulating } \\
\text { sustainable economy to launch the nation among the twenty leading } \\
\text { economies by } 2020\end{array}$ & 499 (92.4\%) & $34(6.3 \%)$ & $5(0.9 \%)$ & $2(0.4 \%)$ & $540(100 \%)$ \\
\hline 3 & $\begin{array}{l}\text { One of the objectives of the Vision } 2020 \text { Policy in Nigeria is raising } \\
\text { Nigerian's industrialized and technological sectors to advanced height by } \\
2020\end{array}$ & $501(92.8 \%)$ & $29(5.4 \%)$ & $7(1.3 \%)$ & $3(0.5 \%)$ & $540(100 \%)$ \\
\hline 4 & $\begin{array}{l}\text { One of the objectives of the Vision } 2020 \text { Policy in Nigeria is the provision of } \\
\text { adequate infrastructure, health services, quality education and food security }\end{array}$ & $516(95.6 \%)$ & $19(3.5 \%)$ & $5(0.9 \%)$ & $0(0 \%)$ & $540(100 \%)$ \\
\hline
\end{tabular}

Source: Authors' Survey, 2018. 
Table 5. A Table showing the Factors Contributing to the Failure of the Previous Developmental Plans in Nigeria

\begin{tabular}{|c|c|c|c|c|c|c|}
\hline $\mathbf{S} / \mathbf{N}$ & Item & SA & A & SD & D & Total \\
\hline 1 & $\begin{array}{l}\text { Some of the factors contributing to the failure of the previous } \\
\text { developmental plans in Nigeria are the instability of the economy } \\
\text { associated with bad governance, embezzlement and low purchasing power } \\
\text { etc }\end{array}$ & 478 (89\%) & $26(4.8 \%)$ & 29 (5.4\%) & 7 (1.3\%) & $540(100 \%)$ \\
\hline 2 & $\begin{array}{l}\text { One of the factors contributing to the failure of the previous } \\
\text { developmental plans in Nigeria is the failure/deplorable disposition of the } \\
\text { educational system in Nigeria }\end{array}$ & 349 (65\%) & 102 (19\%) & $53(10 \%)$ & $36(7 \%)$ & $540(100 \%)$ \\
\hline 3 & $\begin{array}{l}\text { One of the factors contributing to the failure of the previous } \\
\text { developmental plans in Nigeria is the inadequate skilled manpower with } \\
\text { requisite training and experience for economic development }\end{array}$ & 472 (87.4\%) & 36 (7\%) & $233(4.2 \%)$ & $9(1.7 \%)$ & $540(100 \%)$ \\
\hline 4 & $\begin{array}{l}\text { One of the factors contributing to the failure of the previous } \\
\text { developmental plans in Nigeria is high level of poverty contributing to } \\
\text { illiteracy, poor health services, low investments prosperity and inadequate } \\
\text { food security }\end{array}$ & 520 (96.3\%) & 18 (3.3\%) & $2(0.4 \%)$ & $0(0 \%)$ & $540(100 \%)$ \\
\hline
\end{tabular}

Source: Authors’ Survey, 2018.

Table 6. A Table showing some of the measures to adopt to achieve the core objectives of Vision 2020 Policy in Nigeria

\begin{tabular}{|c|c|c|c|c|c|c|}
\hline $\mathrm{S} / \mathrm{N}$ & Item & SA & A & SD & D & Total \\
\hline 1 & $\begin{array}{l}\text { Some of the measures to adopt to achieve the core objectives of } \\
\text { Vision } 2020 \text { Policy in Nigeria are instituting good governance } \\
\text { backed by public trust, discipline and political will }\end{array}$ & 320 (59.3\%) & 205(38\%) & $9(1.7 \%)$ & $6(1.1 \%)$ & $540(100 \%)$ \\
\hline 2 & $\begin{array}{l}\text { One of the measures to adopt to achieve the core objectives of } \\
\text { Vision } 2020 \text { Policy in Nigeria is sustaining viable policies, } \\
\text { projects and programmes in Nigeria }\end{array}$ & 303 (56.1\%) & $216(40 \%)$ & $16(3 \%)$ & $5(0.5 \%)$ & $540(100 \%)$ \\
\hline 3 & $\begin{array}{l}\text { One of the measures to adopt to achieve the core objectives of } \\
\text { Vision } 2020 \text { Policy in Nigeria is rooting out corruption and other } \\
\text { related tendencies out of Nigeria political system }\end{array}$ & $221(50 \%)$ & 191(35.4\%) & 111(21\%) & $17(3.1 \%)$ & $540(100 \%)$ \\
\hline 4 & $\begin{array}{l}\text { One of the measures to adopt to achieve the core objectives of } \\
\text { Vision } 2020 \text { Policy in Nigeria is strengthening the implementation } \\
\text { of structures of Vision plans in Nigeria }\end{array}$ & 401 (74.2\%) & 102 (19\%) & $37(7 \%)$ & $8(1.4 \%)$ & $540(100 \%)$ \\
\hline
\end{tabular}

Source: Authors’ Survey, 2018.

Table 6: A Table showing some of the measures to adopt to achieve the core objectives of Vision 2020 Policy in Nigeria

\section{Analysis:}

In Table 6 finally, the respondents who strongly agreed that some of the measures to adopt to achieve the core objectives of Vision 2020 Policy in Nigeria are instituting good governance backed by public trust, discipline and political will are 320(59.3\%), while 205(38\%) agreed, $9(1.7 \%)$ strongly disagreed and 6(1.1\%) disagreed with the assertion.

The respondents who strongly agreed that one of the measures to adopt to achieve the core objectives of Vision 2020 Policy in Nigeria is sustaining viable policies, projects and programmes in Nigeria are 303(56.1\%), while $216(40 \%)$ agreed, 16(3\%) strongly disagreed and $5(0.5 \%)$ disagreed with the assertion.

The respondents who strongly agreed that one of the measures to adopt to achieve the core objectives of Vision 2020 Policy in Nigeria is rooting out corruption and other related tendencies out of Nigeria political system are 221(50\%), while 191(35.4\%) agreed, 111(21\%) strongly disagreed and $17(3,1 \%)$ disagreed with the assertion.

The respondents who strongly agreed that one of the measures to adopt to achieve the core objectives of Vision 2020 Policy in Nigeria is strengthening the implementation of structures of Vision plans in Nigeria are 401(74.2\%), while 102(19\%) agreed, 37(7\%) strongly disagreed and $8(1.4 \%)$ disagreed with the assertion.

\section{Recommendations}

Nigeria development policies/programmes were noted to have suffered serious institutional and structural problems. This research however recommends some measures for sustainable implementation of vision 20:2020. Good government backed by public confidence, sufficient discipline and political will to enforce policies. Policy continuity/sustenance of variable projects/programmers. Exclusion of partisan and ethnic politics in policy formulation and implementation. Proper orientation. Corruption and all corrupt tendencies should adequately be checked and rooted out of the society. In summary, Adepetun [12] quoted Israeli Envoy to Nigeria, Moshe Ram as saying that Nigeria Vision 20:2020 dream can become a reality if the country can go back to basic agriculture, just as Mayor of London, Mr. Alderman David Lewis observed that Nigerian vision 20:2020 objectives can be achieved when due attention is given to human capital development, sound and qualitative education, training and retraining.

\section{References}

[1] Pearson (2003), Dictionary of Contemporary English, Edinburgh England, Longman PLC.

[2] Ibrahim S, (2009) Science and Technology Catalyst to Achieving Vision 20:20:20: Kastina Sunday Triumph. http:||www.triumphnewspapers.com|Sunday|scc6122009.htm. 
[3] Tadaro, P.M and Smith C.S (2002), Economic Development. $8^{\text {th }}$ Edition, Singapore, pearson Education Inc.

[4] Onyenekenwa, C.E (2011), Nigeria’s Vision 20:20:20 - Issues Challenges and Implications for Development Management, Asian Journal of Rural Development vol1 (1). 2011. 21. 40.

[5] Jhingan, M.L (2007). The Economics of Development and Planning. $39^{\text {th }}$ Edition. Delhi, Vrinda publication Ltd.

[6] Ebigbo, P.O (2008), Appraising the Impact of Economic Reformation Programme on Micro, Small and Medium Scale Enterprises. A paper Delivered at the $19^{\text {th }}$ Enugu International Trade Fair Colloquium, April 15, 2008.

[7] Onah, F.O (2006), Managing Public Programmes and Projects. Nsukka Nigeria. Great A P Express Publishers.
[8] Okigbo, P (1989), National Development Planning in Nigeria 1900-92. Enugu, Fourth Dimension Publishing Co.Ltd.

[9] Eneh O.C (2009), Failed Development Visions, Political Leadership in Nigeria's Development: A Critique proceedings of International Academy of African Business School, Kampala.

[10] Nwori, B. C. (2005), Foreign Policy Analysis: Nigerian Perspective, Abakaliki, Inarrok Syndicate.

[11] Abdulhamid, Y (2008). Nigerian: Vision 2020 and NPC Daily Trust. A Nigerian Daily Newspaper, August 5. http://allafrican.com/stories/200808050705.html

[12] Adepetun, A (2008), How to Actualize Vision 20:20, Lord Mayor of London. Guardian Newspapers. 